\title{
Levedura como pronutriente em dietas para matrizes e alevinos de tilápia- do-nilo ${ }^{1}$
}

\section{João Fernando Albers Koch², Luiz Edivaldo Pezzato ${ }^{3}$, Margarida Maria Barros ${ }^{3}$, Caroline Pelegrina Teixeira ${ }^{2}$, Ademir Calvo Fernandes Junior ${ }^{2}$, Carlos Roberto Padovani ${ }^{4}$}

\author{
1 Pesquisa financiada pela FAPESP (Processo 07/56693-3). \\ 2 Programa de Pós-graduação em Zootecnia, Unesp - Universidade Estadual Paulista, AquaNutri - FMVZ - Campus Botucatu. \\ ${ }^{3}$ Unesp - Universidade Estadual Paulista - FMVZ - Botucatu - São Paulo, 18618-000, Caixa Postal 560. \\ ${ }^{4}$ Departamento de Bioestatística, Instituto de Biociências, Unesp - Botucatu, SP.
}

RESUMO - Objetivou-se avaliar a levedura Saccharomyces cerevisiae como pronutriente em dietas para matrizes e alevinos de tilápia-do-nilo. O experimento foi realizado em duas etapas na UNESP. Dois grupos de fêmeas reprodutoras de tilápia (734,47 \pm 202,08 g), variedade GIFT, foram arraçoados por 100 dias com rações isoproteicas (34\% PD) e isoenergéticas (3.400 kcal ED/kg), uma contendo $2 \%$ de levedura íntegra e outra sem levedura. As fêmeas foram fecundadas naturalmente e as larvas, ao final da absorção do saco vitelino, foram alocadas em aquários de 3,5 L e alimentadas por 30 dias com três rações isoproteicas (35\% PD) e isoenergéticas (3.280 kcal ED/kg): sem levedura; contendo 1\% de levedura íntegra; ou contendo 1\% de levedura autolisada. Após o abate, foram calculadas as seguintes variáveis de desempenho produtivo: biomassa final; ganho de peso; consumo de ração; conversão alimentar aparente; peso final; comprimento total; fator de condição corporal; altura média; e sobrevivência. Foram analisados ainda os teores de matéria seca, matéria mineral, proteína bruta e extrato etéreo da carcaça dos animais. Verificou-se interação significativa dos fatores analisados para todas as variáveis de desempenho produtivo, exceto para o consumo de ração. O fornecimento de levedura íntegra (2,0\%) em dietas para matrizes ou alevinos de tilápia-do-nilo (1,0\%) aumenta a taxa de sobrevivência dos alevinos.

\footnotetext{
Palavras-chave: composição bromatológica, desempenho, GIFT, nutrição, Oreochromis niloticus, Saccharomices
} cerevisiae

\section{Yeast as pro-nutrient in diets for Nile tilapia broodstock females and fingerlings}

\begin{abstract}
This trial was conducted to evaluate dietary yeast Saccharomyces cerevisiae as pro-nutrient for diets for Nile tilapia broodstock females and fingerlings. The trial was conducted in two phases at UNESP. Two groups of tilapia broodstock females (734.47 $\pm 202.08 \mathrm{~g}$ ), GIFT genealogy, were fed with isoprotein (34\% DP) and isoenergy (3400 kcal DE/kg) diets for 100 days, one with $2 \%$ autolized yeast and the other with no yeast. Broodstock females were naturally fecundated, and larvae, at the end of yolk sac absorption, were stocked into 3.5-L aquarium and fed 30 days with three isoprotein (35\% DP) and isoenergy (3280 kcal DE/kg) diets: without yeast, containing 1\% whole yeast or $1 \%$ autolized yeast. After, fingerlings were killed and final biomass; weight gain; ration consumption; apparent feed conversion; final weight; total length; corporal condition factor; mean height and survival were determined. Dry matter, ash, crude protein and ether extract from fish body were also determined. There was interaction of the data analyzed for all growth performance variables, except for feed intake. Supplying whole yeast (2.0\%) in Nile tilapia broodstock female diets or in fingerling diets (1.0\%) improves fingerling survival.
\end{abstract}

Key Words: body composition, GIFT, grow performance, nutrition, Oreochromis niloticus, Saccharomices cerevisiae

\section{Introdução}

O sistema intensivo de produção de larvas e alevinos de tilápia-do-nilo submete os reprodutores a manejos estressantes, e as consequências biológicas e zootécnicas desse estresse ainda não estão esclarecidas. Por outro lado, a adequada nutrição dos reprodutores reflete positivamente na qualidade de gônadas, na formação de ovócitos e, principalmente, na qualidade das larvas produzidas (El-Sayed et al., 2003).

A variedade GIFT (Genetically Improved Farmed Tilapia) originou-se de rigoroso processo de seleção genética (Ponzoni et al., 2005). Apresenta rusticidade ao manejo reprodutivo e excelente desempenho produtivo, que são resultados do elevado grau de resistência às doenças e infecções (Khaw et al., 2008). A crescente 
demanda de alevinos dessa espécie em nosso País tem norteado ações de boas práticas de manejo que aumenta a produção de indivíduos mais saudáveis.

O Brasil é um grande produtor de levedura, tendo em vista a obtenção da Saccharomyces cerevisiae a partir do vinho nas destilarias de álcool de cana-de-açúcar. A levedura íntegra e os derivados do seu processamento, como levedura autolisada, polissacarídeos da parede celular e nucleotídeos, estão sendo recomendados para compor rações para organismos aquáticos. Segundo Hisano et al. (2004), esses subprodutos se destacam pela biossegurança e fácil incorporação à mistura durante o processamento da ração.

Segundo Butolo (2001), a levedura é um ingrediente indispensável às rações, tanto como pronutriente como imunoestimulante. Define-se como pronutriente o composto que promove valores nutricionais intrínsecos, que seja de uso oral e exigido em pequenas quantidades na mistura da dieta animal (Butolo, 2001). Segundo Menten (2001), com a proibição do uso de antibióticos e quimioterápicos como promotores de crescimento na alimentação animal, essas pesquisas se tornaram fundamentais.

Esta pesquisa foi realizada com o objetivo de avaliar os efeitos da levedura íntegra (Saccharomyces cerevisiae) sobre o desempenho reprodutivo de fêmeas de tilápia-donilo e da levedura íntegra e da levedura autolisada sobre o desempenho dos alevinos provenientes dessas matrizes.

\section{Material e Métodos}

A pesquisa foi desenvolvida em duas fases, em laboratórios distintos da UNESP - Universidade Estadual Paulista. A primeira fase experimental foi realizada no laboratório de tilapicultura do Centro de Aquicultura da UNESP (CAUNESP), Jaboticabal, São Paulo, no período de 20 de outubro de 2007 a 30 de janeiro de 2008. Após a seleção, 63 fêmeas e 21 machos reprodutores com aproximadamente 22 meses de idade e peso médio de $734,47 \pm 202,8 \mathrm{~g}$ foram distribuídos inteiramente ao acaso em três aquários de $7.000 \mathrm{~L}$, totalizando 21 fêmeas e 7 machos por aquário, na proporção de $3: 1 / \mathrm{m}^{3}$ (três fêmeas para cada macho). Para cada grupo de 28 animais (21 fêmeas e 7 machos) localizados em cada um dos aquários, foi administrada uma das seguintes rações: ração controle, sem suplementação de levedura; ração suplementada com 2\% de levedura íntegra; ou ração suplementada com $2 \%$ de levedura autolisada. As rações utilizadas foram isoproteicas (34,0\% de PD) e isoenergéticas (3.400 kcal de ED/kg de ração) (Tabela 1$)$.

Os ingredientes selecionados para compor as dietas foram submetidos a análises química e física no Laboratório de Bromatologia da FMVZ - Botucatu, conforme metodologia proposta pela AOAC (2000). Estes ingredientes foram moídos e passados em peneira TYLER 35 para que apresentassem diâmetro médio de $0,5 \mathrm{~mm}$. A mistura foi homogeneizada e submetida ao processo de extrusão em equipamento de rosca simples Extrutec ${ }^{\circledR}$, a fim de se obterem grânulos com 5,0 mm de diâmetro. Após resfriamento, os grânulos foram secos em estufa com circulação de ar a $55,0^{\circ} \mathrm{C} /$ 24 horas e, posteriormente armazenados a $-20,0{ }^{\circ} \mathrm{C}$.

Os peixes foram alimentados quatro vezes ao dia, às 8:00, 11:00, 14:00 e 17:00, até a saciedade aparente, por 100 dias. A temperatura da água dos tanques foi aferida duas vezes ao dia, às 8:00 e 17:00, e o nível de oxigênio dissolvido epH foram aferidos semanalmente por termômetros, oxímetro e peagâmetro digitais. Os valores de temperatura, oxigênio dissolvido e $\mathrm{pH}$ da água mensurados durante o período

Tabela 1 - Composição percentual e químico-bromatológica calculada das dietas fornecidas aos reprodutores ${ }^{1}$

\begin{tabular}{|c|c|c|c|}
\hline \multirow[b]{2}{*}{ Ingrediente } & \multicolumn{3}{|c|}{ Tratamento } \\
\hline & Controle & $\begin{array}{c}\text { Levedura } \\
\text { íntegra }\end{array}$ & $\begin{array}{l}\text { Levedura } \\
\text { autolisada }\end{array}$ \\
\hline Farelo de soja & 63,00 & 62,00 & 62,50 \\
\hline Levedura íntegra & 0,00 & 2,00 & 0,00 \\
\hline Levedura autolisada & 0,00 & 0,00 & 2,00 \\
\hline Farinha de peixe & 2,50 & 2,50 & 2,50 \\
\hline Fubá de milho & 12,40 & 12,20 & 10,90 \\
\hline Farelo de trigo & 2,10 & 2,00 & 2,00 \\
\hline Quirera de arroz & 11,50 & 10,80 & 11,60 \\
\hline Óleo de soja & 3,00 & 3,00 & 3,00 \\
\hline Fosfato bicálcico & 3,15 & 3,15 & 3,15 \\
\hline DL-metionina & 0,70 & 0,70 & 0,70 \\
\hline L-treonina & 0,65 & 0,65 & 0,65 \\
\hline L-triptofano & 0,20 & 0,20 & 0,20 \\
\hline Sal $(\mathrm{NaCl})$ & 0,50 & 0,50 & 0,50 \\
\hline Suplemento vitamínico e mineral ${ }^{2}$ & $2 \quad 0,25$ & 0,25 & 0,25 \\
\hline Antioxidante $(\mathrm{BHT})^{3}$ & 0,02 & 0,02 & 0,02 \\
\hline Vitamina C & 0,03 & 0,03 & 0,03 \\
\hline Total & 100,00 & 100,00 & 100,00 \\
\hline \multicolumn{4}{|l|}{ Nutriente } \\
\hline Energia digestível (kcal/kg) & 3401 & 3401 & 3401 \\
\hline Proteína digestível (\%) & 33,97 & 34,16 & 34,11 \\
\hline Fibra bruta $(\%)$ & 4,97 & 4,93 & 4,90 \\
\hline Extrato etéreo (\%) & 5,74 & 5,71 & 5,65 \\
\hline Cálcio total $(\%)$ & 1,19 & 1,19 & 1,19 \\
\hline Fósforo disponível (\%) & 0,70 & 0,71 & 0,71 \\
\hline Metionina (\%) & 1,06 & 1,06 & 1,06 \\
\hline Aminoácidos sulfurados (\%) & 1,49 & 1,50 & 1,48 \\
\hline Lisina $(\%)$ & 2,59 & 2,61 & 2,61 \\
\hline Triptofano (\%) & 0,53 & 0,53 & 0,53 \\
\hline Treonina (\%) & 1,67 & 1,69 & 1,69 \\
\hline
\end{tabular}

1 Valores com base em: NRC (1993), Pezzato et al. (2002), Gonçalves et al. (2004, 2005), Furuya et al. (2001), Guimarães et al. (2008). Valores expressos com base na matéria seca.

2 Suplemento vitamínico e mineral (níveis de garantia/kg do produto): vit. A = 1.200.000 UI; vit. $\mathrm{D}_{3}=200.000 \mathrm{UI}$; vit. $\mathrm{E}=12.000 \mathrm{mg}$; vit. $\mathrm{K} 3=2.400 \mathrm{mg}$ vit. $B_{1}=4.800 \mathrm{mg} ;$ vit. $B_{2}=4.800 \mathrm{mg}$; vit. $B_{6}=4.000 \mathrm{mg}$; vit. $B_{12}=4.800 \mathrm{mg}$; ácido fólico $=1.200 \mathrm{mg}$; pantotenato de cálcio $=12.000 \mathrm{mg}$; vit. $\mathrm{C}=48.000 \mathrm{mg}$; biotina $=48 \mathrm{mg} ;$ colina $=65.000 \mathrm{mg} ;$ niacina $=24.000 \mathrm{mg}$, ferro $=10.000 \mathrm{mg}$ cobre $=600 \mathrm{mg} ;$ manganês $=4.000 \mathrm{mg} ;$ iodo $=20 \mathrm{mg} ;$ cobalto $=2 \mathrm{mg}$ e selênio $=$ $20 \mathrm{mg}$.

3 Antioxidante $($ BHT) $=$ butil-hidróxi-tolueno. 
experimental apresentaram, respectivamente, os seguintes valores médios: $27,3 \pm 1,1^{\circ} \mathrm{C}$ (manhã) e $28,1 \pm 0,8^{\circ} \mathrm{C}$ (tarde); $6,1 \pm 0,8 \mathrm{mg} / \mathrm{L}$ e 7,3 $\pm 0,4$. Estes valores apresentam-se dentro da faixa considerada adequada para a espécie de acordo com Sipaúba-Tavares (1995). O fotoperíodo foi mantido constante, com 12 horas de luz e 12 horas de escuridão, obtido pelo uso controlado de iluminação artificial com lâmpadas de 400 Watts para cada aquário.

Após 100 dias de arraçoamento, iniciaram-se as avaliações das reprodutoras, realizadas em intervalos de cinco dias. O manejo adotado na captura e avaliação foi o mesmo para todas as fêmeas: aquelas que incubavam ovos eram cuidadosamente manejadas e os ovos removidos da cavidade bucal com auxílio de uma piceta e copos descartáveis. A desova de cada matriz foi acondicionada separadamente em incubadoras devidamente identificadas.

Após a eclosão, ao final da absorção do saco vitelínico, as larvas foram coletadas das incubadoras e colocadas em sacos plásticos específicos para transportes de peixes. Para esse processo, as incubadoras foram inclinadas e as larvas colocadas nos sacos de transporte juntamente com a água da incubadora, acrescida de água limpa. Posteriormente, os sacos foram inflados com oxigênio (2/3 do volume total), amarrados e colocados em caixas com fundo revestido para evitar movimentação exagerada da água.

A segunda fase experimental (estudo - II) foi realizada no período de 30 de janeiro a 29 de fevereiro de 2008, na Universidade Estadual Paulista - UNESP - Câmpus de Botucatu, Faculdade de Medicina Veterinária e Zootecnia, Laboratório de Nutrição de Organismos Aquáticos AquaNutri, Unidade integrada ao CAUNESP.

Foram utilizadas 1.050 larvas, de ambos os sexos, provenientes das matrizes alimentadas com a ração sem suplementação de levedura (controle) ou das matrizes alimentadas com a ração contendo $2 \%$ de levedura íntegra. Não foram utilizadas larvas oriundas de matrizes arraçoadas com rações com $2 \%$ de levedura autolisada, devido ao baixo número de desovas dessas matrizes, e também pelo fato de os eventos reprodutivos não coincidirem com os demais tratamentos, pois as larvas deveriam ser oriundas de desovas colhidas no mesmo dia e em estágio similar de desenvolvimento. Para obtenção do número adequado de larvas para o início dessa fase experimental, realizou-se um pool de larvas de diversas matrizes dentro do mesmo tratamento. Esse procedimento também serviu para reduzir os efeitos referentes às qualidades individuais das matrizes.

Foi aferido o peso médio inicial das larvas pesando-se uma amostra de aproximadamente 50 larvas oriundas de cada um dos dois grupos. Essas larvas foram posteriormente descartadas e não foram utilizadas como material biológico do experimento. O peso médio inicial das larvas oriundas de matrizes que consumiram a dieta controle e daquelas que consumiram a dieta contendo levedura íntegra foi $0,0093 \mathrm{~g}$ e $0,0102 \mathrm{~g}$, respectivamente.

Foram utilizados nessa fase 30 aquários de polietileno com 3,5 L de capacidade útil. Em cada aquário, foram colocadas 35 larvas (10 larvas/litro), de modo que 15 aquários foram povoados com larvas oriundas de matrizes que consumiram a dieta controle e os outros 15 com larvas de matrizes que consumiram dietas com levedura íntegra. Os aquários foram interligados por sistema de recirculação de água dotado de filtro físicobiológico. O filtro continha pedras porosas ligadas por meio de mangueiras a soprador, com a finalidade de melhorar o ambiente de atuação de bactérias e aumentar a oxigenação da água. Para manter a temperatura da água na faixa de conforto térmico da espécie, aquecedores foram ligados em termostatos e acoplados ao sistema.

Para o estudo II foram formuladas três rações (Tabela 2) isoproteicas (35\% de PD) e isoenergéticas (3300 kcal de ED/kg de ração): uma denominada dieta controle, sem os pronutrientes em estudo, e duas formuladas com 1,0\% de levedura íntegra; ou 1,0\% de levedura autolisada.

Os seis tratamentos avaliados na segunda fase experimental foram:

Matriz (ração controle) + alevino (ração controle);

Matriz (ração controle) + alevino (ração levedura íntegra);

Matriz (ração controle) + alevino (ração levedura autolisada);

Matriz (ração levedura íntegra) + alevino (ração controle);

Matriz (ração levedura íntegra) + alevino (ração levedura íntegra);

Matriz (ração levedura íntegra) + alevino (ração levedura autolisada).

Para confecção das dietas dos alevinos, os ingredientes foram moídos e passados em peneira Tyler-35 para que atingissem diâmetro médio de $0,42 \mathrm{~mm}$. Após a homogeneização dos ingredientes, foram adicionados $22 \%$ de água $\left(55^{\circ} \mathrm{C}\right)$ e a ração foi submetida ao processo de peletização. Posteriormente, a ração foi seca em estufa com circulação de ar a $55,0^{\circ} \mathrm{C} / 24$ horas e armazenada a $-20,0^{\circ} \mathrm{C}$.

Para serem fornecidos aos alevinos, os péletes foram triturados e posteriormente separados com o uso de peneiras em três granulometrias:

a) grânulos que passavam pela abertura de $0,42 \mathrm{~mm}$ (TYLER 35). Esta fração foi fornecida nos dez primeiros dias de experimento; 
b) grânulos que passavam pela abertura de $0,71 \mathrm{~mm}$ (TYLER 24) e ficavam retidos na peneira de 0,42 mm. Fração fornecida do $11^{\circ}$ ao $20 \underline{0}$ dia experimental;

c) grânulos que passavam pela abertura de $1,00 \mathrm{~mm}$ (TYLER 16) e ficavam retidos na peneira de $0,71 \mathrm{~mm}$. Fração fornecida do $21^{\circ}$ ao 30 을 dia experimental.

Os objetivos na separação das frações das rações em três tamanhos foi adequar o tamanho do alimento ao tamanho da boca dos alevinos, de acordo com seu desenvolvimento, e diminuir a lixiviação dos ingredientes e sua seleção pelos animais.

Os alevinos foram alimentadas cinco vezes ao dia, às 8:00, 10:00, 12:00, 14:00 e 17:00, até a saciedade aparente. Os aquários foram sifonados uma vez por dia após 30 minutos da última refeição nos primeiros 10 dias e a cada três dias nos demais dias de experimento, devido à maior granulometria das rações. Após cada sifonagem, foi

Tabela 2 - Composição percentual e químico-bromatológica calculada das dietas fornecidas aos alevinos ${ }^{1}$

\begin{tabular}{|c|c|c|c|}
\hline \multirow[b]{2}{*}{ Ingrediente } & \multicolumn{3}{|c|}{ Tratamento } \\
\hline & Controle & $\begin{array}{l}\text { Levedura } \\
\text { íntegra }\end{array}$ & $\begin{array}{c}\text { Levedura } \\
\text { autolisada }\end{array}$ \\
\hline Farinha de vísceras de aves & 20,73 & 20,77 & 20,77 \\
\hline Quirera de arroz & 21,00 & 20,00 & 20,00 \\
\hline Farinha de peixe & 53,00 & 53,00 & 53,00 \\
\hline Levedura íntegra & 0,00 & 1,00 & 0,00 \\
\hline Levedura autolisada & 0,00 & 0,00 & 1,00 \\
\hline DL-metionina & 0,11 & 0,10 & 0,10 \\
\hline L-triptofano & 0,16 & 0,15 & 0,15 \\
\hline L-treonina & 0,20 & 0,18 & 0,18 \\
\hline Fosfato bicálcico & 4,00 & 4,00 & 4,00 \\
\hline Vitamina $\mathrm{C}$ & 0,03 & 0,03 & 0,03 \\
\hline Sal $(\mathrm{NaCl})$ & 0,50 & 0,50 & 0,50 \\
\hline Suplemento vitamínico ${ }^{2}$ & 0,15 & 0,15 & 0,15 \\
\hline Suplemento mineral ${ }^{3}$ & 0,10 & 0,10 & 0,10 \\
\hline Butil-hidróxi-tolueno ${ }^{4}$ & 0,02 & 0,02 & 0,02 \\
\hline Total & 100 & 100 & 100 \\
\hline \multicolumn{4}{|l|}{ Nutriente } \\
\hline Energia digestível (kcal/kg) & 3274 & 3280 & 3284 \\
\hline Proteína digestível (\%) & 35,14 & 35,41 & 35,34 \\
\hline Fibra bruta $(\%)$ & 0,57 & 0,57 & 0,57 \\
\hline Extrato etéreo (\%) & 9,79 & 9,71 & 9,71 \\
\hline Cálcio total (\%) & 4,93 & 4,93 & 4,93 \\
\hline Fósforo disponível (\%) & 1,92 & 1,92 & 1,92 \\
\hline Metionina (\%) & 1,13 & 1,12 & 1,12 \\
\hline Aminoácidos sulfurados (\%) & 1,09 & 1,08 & 1,08 \\
\hline Lisina (\%) & 3,08 & 3,11 & 3,10 \\
\hline Triptofano (\%) & 0,46 & 0,45 & 0,45 \\
\hline Treonina (\%) & 1,70 & 1,69 & 1,69 \\
\hline
\end{tabular}

${ }^{1}$ Valores com base em: NRC (1993); Pezzato et al. (2002); Gonçalves et al. (2004; 2005); Furuya et al. (2001); Hisano (2005); Guimarães (2006). Valores expressos com base na matéria seca.

${ }^{2}$ Suplemento vitamínico (níveis de garantia/kg do produto): vit. $\mathrm{A}=1.200 .000$ UI; vit. $\mathrm{D}_{3}=200.000 \mathrm{UI}$; vit. $\mathrm{E}=12.000 \mathrm{mg}$; vit. $\mathrm{K} 3=2.400 \mathrm{mg}$; vit. $\mathrm{B}_{1}=4.800 \mathrm{mg}$; vit. $\mathrm{B}_{2}=4.800 \mathrm{mg}$; vit. $\mathrm{B}_{6}=4.000 \mathrm{mg}$; vit. $\mathrm{B}_{12}=4.800 \mathrm{mg}$; ácido fólico $=1.200 \mathrm{mg}$; pantotenato de cálcio $=12.000 \mathrm{mg}$; vit. $\mathrm{C}=48.000 \mathrm{mg}$; biotina $=48 \mathrm{mg}$; colina $=$ $65.000 \mathrm{mg}$; niacina $=24.000 \mathrm{mg}$

${ }^{3}$ Suplemento mineral (níveis de garantia/kg do produto): ferro $=10.000 \mathrm{mg}$; cobre $=$ $600 \mathrm{mg}$; manganês $=4.000 \mathrm{mg} ;$ iodo $=20 \mathrm{mg} ;$ cobalto $=2 \mathrm{mg}$ e selênio $=20 \mathrm{mg}$.

${ }^{4}$ Antioxidante $(\mathrm{BHT})=$ butil-hidróxi-tolueno. adicionado tiossulfato de sódio para neutralizar o cloro presente na água de reposição.

A temperatura da água foi aferida duas vezes ao dia, imediatamente antes da circulação s der desligada para o primeiro e último trato. $\mathrm{O}$ teor de oxigênio dissolvido e o $\mathrm{pH}$ da águaos aquários foram aferidos semanalmente. Os valores de temperatura, oxigênio dissolvido e pH da água mensurados durante o período experimental apresentaram, respectivamente, os seguintes valores: $28,98 \pm 1,75{ }^{\circ} \mathrm{C}$; $5,43 \pm 0,05 \mathrm{mg} / \mathrm{L}$ e 7,87 $\pm 0,06$. Estes valores apresentam-se dentro da faixa considerada adequada para a espécie de acordo com Sipaúba-Tavares (1995).

Ao término do período de arraçoamento, que teve duração de 30 dias, todos os alevinos de cada unidade experimental foram abatidos em água a $1{ }^{\circ} \mathrm{C}$, pelo uso de pedras de gelo. Posteriormente, foram colocados em prancheta de papelão impermeabilizada e numerada para que fossem contados e tivessem o peso e comprimento total mensurados individualmente. Devido ao número de tratamentos e repetições empregados no experimento (30 aquários), essa fase de coleta de dados foi realizada em dois dias, esquematizada de maneira que o mesmo número de repetições de todos os tratamentos fosse avaliado em um mesmo dia, a fim de padronizar as condições experimentais.

Foram calculadas as variáveis de desempenho produtivo: biomassa final (BF); ganho de peso (GP); consumo de ração (CR); conversão alimentar aparente (CAA); comprimento total (CT); peso final (PF); fator de condição corporal (FCC); altura média (AM); e sobrevivência (SOB):

$\mathrm{BF}(\mathrm{g})=\Sigma$ peso dos peixes da unidade experimental;

$\mathrm{GP}(\mathrm{g})$ = (média do peso final - média do peso inicial);

$\mathrm{CR}(\mathrm{g})=$ (total de ração fornecido aos peixes da unidade experimental / número de peixes);

$\mathrm{CAA}=\mathrm{CR} / \mathrm{GP}$;

$\mathrm{CT}(\mathrm{cm})=$ média do comprimento total (medida do lábio superior à extremidade da nadadeira caudal);

$\mathrm{PF}(\mathrm{g})=\mathrm{BF} /$ número de peixes;

FCC $=\left(\right.$ peso $/$ comprimento $\left.^{3}\right) \times 100$;

$\mathrm{AM}=$ média da altura dorsal dos animais;

SOB $(\%)$ = mediana (\% mínima entre as repetições : \% máxima entre as repetições).

Para determinação da composição bromatológica, todos os alevinos de cada unidade experimental (aquário) foram colocados, imediatamente após as medições e pesagens, em recipientes plásticos devidamente identificados. Posteriormente, os frascos foram tampados e acondicionados em freezer à temperatura de $-20^{\circ} \mathrm{C}$. Essas amostras foram levadas para o Laboratório de Bromatologia da FMVZ - Botucatu, onde, conforme metodologia proposta pela AOAC (2000), foram determinados os teores de matéria 
seca, matéria mineral, proteína bruta e extrato etéreo. Para a realização das análises de matéria seca e matéria mineral, os peixes foram colocados inteiros nos cadinhos de porcelana (2 a 3 peixes por cadinho).

Para determinação do conteúdo de proteína bruta, os peixes que restaram nos recipientes plásticos, oriundos de cada uma das unidades experimentais, foram processados separadamente. Todas as análises foram realizadas em duplicata.

Para todas as variáveis, exceto mortalidade, a metodologia estatística adotada foi a técnica da análise de variância paramétrica para o modelo com dois fatores no delineamento inteiramente casualizado, complementada com o teste de comparações múltiplas de Tukey (ZAR, 1999). Os dados de sobrevivência foram avaliados por análise de variância não-paramétrica para o modelo com dois fatores complementada com o teste de comparações múltiplas de Dunn (ZAR, 1999). O sistema adotado foi o Sistema de Análises Estatísticas e Genéticas, SAEG (UFV, 1997).

\section{Resultados e Discussão}

Verificou-se interação significativa $(\mathrm{P}<0,05)$ dos fatores avaliados para as variáveis de desempenho produtivo, exceto consumo de ração (Tabela 3). Nos grupos alimentados com o mesmo tipo de ração, a biomassa final e o ganho de peso não foram influenciados pelas dietas fornecidas às matrizes (controle ou íntegra). Os alevinos provenientes de matrizes arraçoadas com ração controle (ausente da suplementação de levedura), quando receberam ração com 1\% de levedura íntegra ou ração sem levedura, apresentaram valores maiores e semelhantes entre si, para ambas as variáveis, em relação aos alevinos que receberam ração suplementada com $1 \%$ de levedura autolisada.

Quando as matrizes receberam a suplementação de levedura na ração, o mesmo não ocorreu, revelando valores semelhantes para esses parâmetros, independentemente do tratamento fornecido ao alevino. Apesar de nãosignificativa, verificou-se queda nos valores de biomassa final proporcionada pela presença da levedura autolisada nas rações dos alevinos, cujas matrizes foram arraçoadas com levedura íntegra. A biomassa final pode ser considerada a variável mais importante em trabalhos de larvicultura de peixes. Isso porque essa variável engloba a taxa de sobrevivência e o peso final médio dos animais.

Esses resultados divergem dos dados de ganho de peso médio encontrados por Pezzato et al. (2006), que, trabalhando com alevinos da mesma espécie, demonstraram não haver diferenças significativas para essa variável entre os tratamentos avaliados (Dieta controle; 2,0\% de levedura íntegra; 2,0\% de levedura autolisada; e $0,3 \%$ de parede celular).

Na análise do consumo de ração, não houve interação dos fatores avaliados. O consumo de ração por alevino foi semelhante para todos os tratamentos $(\mathrm{P}>0,05)$.

Apesar de serem coletadas de desovas do mesmo dia e terem a mesma idade, as larvas oriundas de matrizes que consumiram a ração controle eram mais leves $(0,0093 \mathrm{~g})$ que aquelas oriundas de matrizes que consumiram a dieta

Tabela 3 - Desempenho produtivo e sobrevivência de alevinos de tilápia-do-nilo alimentados com rações contendo levedura íntegra ou autolisada

\begin{tabular}{|c|c|c|c|c|}
\hline \multirow[t]{2}{*}{ Variável } & \multirow[t]{2}{*}{ Dieta das matrizes } & \multicolumn{3}{|c|}{ Dieta dos alevinos } \\
\hline & & Controle & Levedura íntegra & Levedura autolisada \\
\hline \multirow[t]{2}{*}{ Biomassa final (g) } & Controle & $12,89 \pm 0,90 \mathrm{aB}$ & $12,22 \pm 0,71 \mathrm{aB}$ & $10,60 \pm 1,40 \mathrm{aA}$ \\
\hline & Levedura íntegra & $12,37 \pm 0,63 \mathrm{aA}$ & $12,21 \pm 0,78 \mathrm{aA}$ & $11,53 \pm 0,69 \mathrm{aA}$ \\
\hline \multirow[t]{2}{*}{ Ganho de peso (g) } & Controle & $0,37 \pm 0,03 \mathrm{aB}$ & $0,35 \pm 0,01 \mathrm{aB}$ & $0,31 \pm 0,03 \mathrm{aA}$ \\
\hline & Levedura íntegra & $0,34 \pm 0,02 \mathrm{aA}$ & $0,34 \pm 0,02 \mathrm{aA}$ & $0,32 \pm 0,02 \mathrm{aA}$ \\
\hline \multirow[t]{2}{*}{ Consumo de ração (g) } & Controle & $0,29 \pm 0,02 \mathrm{aA}$ & $0,29 \pm 0,01 \mathrm{aA}$ & $0,28 \pm 0,01 \mathrm{aA}$ \\
\hline & Levedura íntegra & $0,28 \pm 0,01 \mathrm{aA}$ & $0,27 \pm 0,01 \mathrm{aA}$ & $0,27 \pm 0,01 \mathrm{aA}$ \\
\hline \multirow[t]{2}{*}{ Conversão alimentar aparente } & Controle & $0,79 \pm 0,03 a \mathrm{~A}$ & $0,81 \pm 0,03 \mathrm{aB}$ & $0,90 \pm 0,11 \mathrm{aB}$ \\
\hline & Levedura íntegra & $0,82 \pm 0,03 a A$ & $0,80 \pm 0,07 a A$ & $0,83 \pm 0,04 \mathrm{aA}$ \\
\hline \multirow[t]{2}{*}{ Peso final (g) } & Controle & $0,39 \pm 0,04 \mathrm{bB}$ & $0,37 \pm 0,01 \mathrm{aB}$ & $0,33 \pm 0,02 \mathrm{aA}$ \\
\hline & Levedura íntegra & $0,35 \pm 0,01 \mathrm{aA}$ & $0,35 \pm 0,02 \mathrm{aA}$ & $0,33 \pm 0,02 \mathrm{aA}$ \\
\hline \multirow[t]{2}{*}{ Comprimento total $(\mathrm{cm})$} & Controle & $2,97 \pm 0,08 \mathrm{aC}$ & $2,84 \pm 0,02 \mathrm{aB}$ & $2,76 \pm 0,06 a \mathrm{~A}$ \\
\hline & Levedura íntegra & $2,93 \pm 0,02 \mathrm{aB}$ & $2,89 \pm 0,06 \mathrm{aB}$ & $2,83 \pm 0,04 \mathrm{bA}$ \\
\hline \multirow[t]{2}{*}{ Fator de condição corporal } & Controle & $1,48 \pm 0,04 \mathrm{bA}$ & $1,60 \pm 0,03 \mathrm{bB}$ & $1,60 \pm 0,05 b B$ \\
\hline & Levedura íntegra & $1,41 \pm 0,06 \mathrm{aA}$ & $1,47 \pm 0,03 a \mathrm{~A}$ & $1,45 \pm 0,03 a \mathrm{~A}$ \\
\hline \multirow[t]{2}{*}{ Altura média (cm) } & Controle & $0,87 \pm 0,02 \mathrm{bB}$ & $0,85 \pm 0,01 \mathrm{bB}$ & $0,84 \pm 0,02 \mathrm{bA}$ \\
\hline & Levedura íntegra & $0,82 \pm 0,01 \mathrm{aA}$ & $0,83 \pm 0,01 \mathrm{aA}$ & $0,82 \pm 0,01 \mathrm{aA}$ \\
\hline \multirow[t]{2}{*}{ Sobrevivência ${ }^{1}$} & Controle & $97,14(88,57: 97,14) \mathrm{bA}$ & $94,28(85,71: 100,0) a A$ & $94,28(77,14: 97,14) \mathrm{bA}$ \\
\hline & Levedura íntegra & $100,0(97,14: 100,0) a A$ & $100,0(97,14: 100,0) a A$ & $100,0(100,0: 100,0) \mathrm{aA}$ \\
\hline
\end{tabular}

Médias seguidas de letras distintas, minúsculas nas colunas para o fator dieta das matrizes e maiúsculas nas linhas para o fator dieta dos alevinos, diferem (P<0,05) entre si. ${ }^{1}$ Mediana: (\% mínima de sobrevivência entre as repetições: \% máxima de sobrevivência entre as repetições).

Teste de comparações múltiplas de Dunn. 
contendo levedura íntegra $(0,0102)$. Mesmo com a diferença inicial de peso (aproximadamente 10\%), o consumo de ração durante o período experimental foi semelhante para todos os tratamentos, demonstrando que as larvas que iniciaram mais leves no estudo II ainda conseguiram, apesar de nãosignificativo $(\mathrm{P}>0,05)$, ter maior consumo de ração em relação às larvas que iniciaram mais pesadas. Estes resultados contrariam os obtidos por Pezzato et al. (2006), que, trabalhando com alevinos pós-revertidos de tilápia-do-nilo $(0,27 \mathrm{~g})$, encontraram menor consumo de ração em póslarvas arraçoadas com $2 \%$ de levedura autolisada em comparação às controle (ausente de levedura) e àquelas alimentadas com a ração com $2 \%$ de levedura íntegra ou com $0,3 \%$ de parede celular.

Houve interação significativa entre os fatores para a conversão alimentar aparente. Quando as matrizes consumiram rações contendo levedura íntegra, independentemente da ração fornecida aos alevinos, não foram encontradas diferenças para essa variável. No entanto, quando foram alimentadas com a ração controle, houve diferenças nos resultados $(\mathrm{P}<0,05)$, pois a ração controle proporcionou melhor conversão alimentar dos alevinos e a ração contendo levedura autolisada a pior, ambas não diferindo dos alevinos que tiveram suas rações suplementadas com levedura íntegra. Esses resultados contrariam os obtidos por Pezzato et al. (2006), que encontraram melhor conversão alimentar em alevinos pósrevertidos de tilápia-do-nilo alimentados com ração contendo $2 \%$ de levedura autolisada em comparação a uma ração controle e a outra contendo 2\% de levedura íntegra.

O consumo de ração foi a única variável que não apresentou interação dos fatores analisados $(\mathrm{P}>0,05)$. Dessa forma, como o consumo de ração foi semelhante $(\mathrm{P}>0,05)$ para todas as rações, o peso final foi reflexo da conversão alimentar aparente.

Para o peso final, também houve interação $(\mathrm{P}<0,05)$ dos fatores analisados. Quando os alevinos consumiram ração controle (ausente de levedura), aqueles gerados por matrizes alimentadas também com ração controle apresentaram maior peso final superior em relação àqueles gerados por matrizes que consumiram ração contendo levedura. Essa diferença ocorreu principalmente devido à melhor conversão alimentar dos alevinos do grupo em que matrizes e alevinos foram alimentadas com a ração controle $(0,79)$ em relação ao grupo em que as matrizes foram alimentadas com a ração contendo levedura íntegra e os alevinos com ração controle $(0,82)$, que, apesar de não-significativa $(\mathrm{P}>0,05)$, foi suficiente para promover aumento $(\mathrm{P}<0,05)$ da média de peso final.

O peso final médio dos alevinos, nos três grupos, foi alterado pelas rações fornecidas aos alevinos. O fornecimento de levedura autolisada para os alevinos proporcionou a menor $(\mathrm{P}<0,05)$ média de peso final.

Para comprimento total, houve interação dos fatores analisados $(\mathrm{P}<0,05)$. Fixando-se o tratamento empregado às matrizes e estudando as respostas às rações fornecidas para os alevinos, verificou-se que, quando as matrizes foram alimentadas com ração controle, o valor dessa variável foi decrescente no sentido: ração controle, ração com levedura íntegra e ração com levedura autolisada. No grupo em que as matrizes receberam ração com levedura íntegra, obteve-se o maior valor de comprimento total para os alevinos que consumiram a ração controle $(\mathrm{P}<0,05)$ e o menor valor para os alevinos que receberam a levedura autolisada $(\mathrm{P}<0,05)$. Os resultados de ambos os grupos, no entanto, não diferiram $(\mathrm{P}>0,05)$ estatisticamente dos obtidos nos alevinos cuja ração continha levedura íntegra. O comprimento total dos alevinos foi a única variável de desempenho produtivo analisada neste trabalho que diferiu $(\mathrm{P}<0,05)$ entre os grupos cujas matrizes receberam levedura íntegra em suas dietas.

Em análise do comprimento total, houve diferença $(\mathrm{P}<0,05)$ entre os grupos em que os alevinos receberam levedura autolisada. O crescimento foi maior naqueles oriundos de matrizes que consumiram a dieta contendo levedura íntegra, em comparação aos alevinos gerados por matrizes que consumiram a dieta sem levedura (controle).

A literatura relaciona o comprimento médio dos peixes à disponibilidade de espaço, de modo que, nos aquários em que houvesse maior mortalidade, os peixes cresceriam mais. Isso não pôde ser comprovado neste estudo, pois o grupo em que as matrizes receberam a dieta com levedura íntegra e os alevinos levedura autolisada, a taxa de sobrevivência dos alevinos foi de $100 \%$ e o comprimento médio de $2,83 \mathrm{~cm}$, enquanto no grupo em que as matrizes receberam a dieta controle e os alevinos a dieta com levedura autolisada a taxa de sobrevivência foi de aproximadamente $90 \%$ e o comprimento médio, de $2,76 \mathrm{~cm}$. Esses resultados comprovam claramente que o comprimento médio não pode ser relacionado apenas à disponibilidade de espaço para os animais, mas principalmente à qualidade da dieta fornecida.

Houve interação significativa dos fatores para o fator de condição corporal. Independentemente das rações fornecidas aos alevinos (controle; levedura íntegra ou; levedura autolisada), os mesmos sempre apresentaram maiores valores para o fator de condição corporal $(\mathrm{P}<0,05)$ quando suas matrizes foram alimentadas com ração sem levedura (controle), em relação àqueles oriundos de matrizes que se alimentaram com ração contendo levedura. Entre os alevinos que foram gerados por matrizes que consumiram a 
ração controle, aqueles que tiveram suas rações suplementadas com levedura íntegra ou levedura autolisada apresentaram valores de fator de condição corporal maiores $(P<0,05)$, e semelhantes entre si, em relação aos alevinos que consumiram a ração controle. Para os alevinos oriundos de matrizes alimentadas com levedura, o mesmo não ocorreu, pois não houve diferenças nessa variável, independentemente da ração fornecida aos alevinos.

O fator de condição corporal expressa o "status corpóreo do animal”, demonstrando se este possui peso adequado para seu comprimento. Essa variável pode dar indicativos de futuros rendimentos de filés desses animais. $\mathrm{O}$ fator de condição corporal dos alevinos oriundos de matrizes que consumiram levedura foi sempre menor $(\mathrm{P}<0,05)$ em comparação aos alevinos que receberam o mesmo tipo de ração, mas se originaram de matrizes que consumiram a dieta controle. Isso foi devido, de maneira geral, ao maior comprimento dos alevinos pertencentes aos tratamentos em que as matrizes consumiram a levedura em suas dietas.

A altura média também foi influenciada pelas rações fornecidas às matrizes. Independentemente da ração fornecida aos alevinos, os mesmos sempre apresentaram maior altura média $(\mathrm{P}<0,05)$ quando suas progenitoras consumiram ração sem levedura (controle). No grupo em que as matrizes consumiram ração contendo levedura íntegra, a altura média de seus alevinos não foi diferente $(\mathrm{P}>0,05)$, independentemente da ração fornecida aos alevinos. O mesmo não ocorreu com essa variável quando as matrizes receberam a ração controle: os alevinos que também consumiram a ração controle foram os mais altos $(\mathrm{P}<0,05)$ e aqueles que consumiram a levedura autolisada os de menor altura média, não diferindo estatisticamente daqueles que consumiram a levedura íntegra.

Houve interação significativa para a taxa de sobrevivência $(\mathrm{P}<0,05)$. A sobrevivência dos alevinos alterou de acordo com as rações fornecidas às matrizes que os originaram. Analisando-se os alevinos que consumiram a ração controle ou dieta contendo levedura autolisada, verificou-se menor sobrevivência $(\mathrm{P}<0,05)$, para ambos os grupos, quando esses alevinos foram gerados por matrizes que se alimentaram de rações sem levedura (controle) em comparação àqueles originados de matrizes que consumiram levedura. Os alevinos que receberam ração contendo levedura íntegra não diferiram quanto às taxas de sobrevivência, independentemente das rações fornecidas às matrizes que os deram origem.

Fixando-se as rações fornecidas às matrizes, não houve variações nas taxas de sobrevivência proporcionadas pelas dietas fornecidas aos alevinos $(\mathrm{P}>0,05)$. Esses resultados diferem dos obtidos por Li \& Gatlin III (2003), que suplementaram dietas para striped bass (Morone chrysops $\times$ M. saxatilis) com três níveis de levedura de cerveja $(1,0 ; 2,0$ e $4,0 \%)$ e avaliaram em comparação a uma dieta controle (ausente de suplementação). Esses autores observaram melhora na sobrevivência e resposta imune das larvas que receberam levedura nas dietas.

A maior taxa de sobrevivência $(\mathrm{P}<0,05)$, exceto para os grupos em que os alevinos receberam levedura íntegra nas dietas, foi registrada no grupo em que os alevinos eram oriundos de matrizes que receberam levedura em suas dietas. Segundo Machado (1997), entre os grupos de nutrientes presentes nas leveduras, pode-se citar os antibióticos naturais, os glucanos e mananos presentes na parede celular, aminoácidos como os glutamatos, que somados proporcionam maior palatabilidade ao alimento e melhor resistência dos animais a doenças. Essas características da levedura na nutrição das reprodutoras podem ter sido responsáveis pelas maiores taxas de sobrevivência dos alevinos oriundos dos grupos em que as matrizes consumiram a levedura.

Analisando os dados de desempenho produtivo, verificou piora nos resultados quando os alevinos foram alimentados com dietas contendo a levedura autolisada. Esse quadro foi amenizado quando as matrizes receberam em suas dietas a suplementação da levedura íntegra durante o período reprodutivo.

Houve interação significativa $(\mathrm{P}<0,05)$ da ração fornecida às matrizes e da ração fornecida aos alevinos sobre a composição bromatológica dos alevinos somente para o conteúdo de matéria seca (Tabela 4). No grupo em que as matrizes foram alimentadas com ração contendo levedura íntegra, os alevinos apresentaram maior teor de matéria seca na carcaça $(\mathrm{P}<0,05)$ em relação àqueles gerados por matrizes que consumiram a ração controle.

Não houve diferenças estatísticas significativas entre as dietas $(\mathrm{P}>0,05)$ para os teores de proteína bruta, matéria mineral e extrato etéreo. Hisano et al. (2007) não encontraram diferenças na composição bromatológica de alevinos de tilápia-do-nilo (2,22 g) arraçoados por 80 dias com dietas suplementadas com três níveis (1, 2 e $3 \%$ ) de levedura íntegra ou autolisada e três níveis de parede celular de levedura $(0,1 ; 0,2$ e $0,3 \%)$. Os dados de composição corporal média da matéria seca, proteína bruta, matéria mineral e extrato etéreo dos alevinos encontrados por esses autores, foram respectivamente 18,0; 15,70; 1,05 e 1,08\%.

Os dados de matéria mineral, proteína bruta e extrato etéreo da carcaça dos animais deste estudo corroboram os resultados obtidos por Pezzato et al. (2006), que suplementaram dietas para alevinos de tilápia-do-nilo $(0,27 \mathrm{~g})$ com levedura íntegra (2,0\%), levedura autolisada $(2,0 \%)$ ou 
Tabela 4 - Composição corporal, na matéria natural, de alevinos de tilápia-do-nilo arraçoados por 30 dias com as dietas experimentais

\begin{tabular}{|c|c|c|c|c|}
\hline \multirow[t]{2}{*}{ Variável (\%) } & \multirow[t]{2}{*}{ Dieta das matrizes } & \multicolumn{3}{|c|}{ Dieta dos alevinos } \\
\hline & & Controle & Íntegra & Autolisada \\
\hline \multirow[t]{2}{*}{ Matéria seca } & Controle & $23,56 \pm 0,52 \mathrm{aA}$ & $22,96 \pm 0,63 \mathrm{aA}$ & $22,76 \pm 0,35 \mathrm{aA}$ \\
\hline & Íntegra & $23,78 \pm 0,35 a A$ & $23,76 \pm 0,94 \mathrm{bA}$ & $23,27 \pm 0,70 \mathrm{aA}$ \\
\hline \multirow[t]{2}{*}{ Matéria mineral } & Controle & $3,19 \pm 0,22 \mathrm{aA}$ & $3,17 \pm 0,23 \mathrm{aA}$ & $3,17 \pm 0,16 \mathrm{aA}$ \\
\hline & Íntegra & $3,32 \pm 0,30 \mathrm{aA}$ & $3,40 \pm 0,19 a \mathrm{~A}$ & $3,14 \pm 0,22 \mathrm{aA}$ \\
\hline \multirow[t]{2}{*}{ Proteína bruta } & Controle & $15,61 \pm 0,54 \mathrm{aA}$ & $14,75 \pm 0,56 \mathrm{aA}$ & $15,53 \pm 0,95 \mathrm{aA}$ \\
\hline & Íntegra & $15,20 \pm 0,93 a A$ & $14,99 \pm 0,46 \mathrm{aA}$ & $15,62 \pm 1,05 \mathrm{aA}$ \\
\hline \multirow[t]{2}{*}{ Extrato etéreo } & Controle & $5,40 \pm 0,72 \mathrm{aA}$ & $5,64 \pm 0,62 \mathrm{aA}$ & $4,90 \pm 1,38 \mathrm{aA}$ \\
\hline & Íntegra & $6,32 \pm 0,90 \mathrm{aA}$ & $4,97 \pm 0,66 \mathrm{aA}$ & $5,51 \pm 0,55 \mathrm{aA}$ \\
\hline
\end{tabular}

Médias seguidas de letras distintas, minúsculas nas colunas para o fator dieta das matrizes e maiúsculas nas linhas para o fator dieta dos alevinos, diferem entre si ( $\mathrm{P}<0,05)$.

parede celular (0,3\%) por 28 dias e não encontraram diferenças na composição corporal dos animais.

O teor de proteína bruta da carcaça dos peixes deste estudo não foi modificado pela presença da levedura na ração. Nesse mesmo sentido, Signor (2009) forneceu dietas para matrizes de tilápia-do-nilo com 1,0; 2,0 e 4,0\% de levedura íntegra, além de uma dieta controle (ausente de suplementação); e não notou variações $(\mathrm{P}>0,05)$ nos teores de umidade, cinzas e extrato etéreo na carcaça das larvas oriundas dessas matrizes logo após a absorção do saco vitelínico. Esse mesmo trabalho, contudo, revelou diferenças $(\mathrm{P}<0,05)$ no teor de proteína bruta da carcaça das larvas, sendo que as matrizes que tiveram suas dietas suplementadas com $4,0 \%$ de levedura proporcionaram larvas com teor de proteína corporal aproximadamente $32,0 \%$ superior às larvas que originaram de matrizes alimentadas com a dieta controle (ausente de suplementação). Esses resultados comprovam que a presença de levedura em maiores porcentagens modifica o teor de proteína na carcaça dos animais.

\section{Conclusões}

O fornecimento de levedura íntegra (2,0\%) em dietas para matrizes ou alevinos de tilápia-do-nilo $(1,0 \%)$ aumenta a taxa de sobrevivência dos alevinos.

\section{Agradecimentos}

À FAPESP (Processo 07/56693-3), pela concessão da bolsa de estudo e, à equipe do laboratório de tilapicultura do Caunesp, pela ajuda prestada.

\section{Referências}

ASSOCIATION OF OFFICIAL AGRICULTURAL CHEMISTS AOAC. Official methods of analysis. 12.ed. Washington, D.C., 2000. 1219p.
BUTOLO, J.E. Leveduras vivas e termolizadas na alimentação animal. In: SIMPÓSIO SOBRE INGREDIENTES ALTERNATIVOS NA ALIMENTAÇÃO ANIMAL, 2001, Campinas. Anais.. Campinas, 2001. p.191-198.

EL-SAYED, A.F.M.; MANSOUR. C.R.; EZZAT, A.A. Effects of dietary protein level on spawning performance of Nile tilapia (Oreochromis niloticus) broodstock reared at different water salinities. Aquaculture, v.220, p.619-632. 2003.

FURUYA, W.M.; PEZZATO, L.E.; PEZZATO, A.C. et al. Coeficientes de digestibilidade e valores de aminoácidos digestíveis de alguns ingredientes para Tilápia do Nilo (Oreochromis niloticus). Revista Brasileira de Zootecnia, v.30, p.1143-1149, 2001.

GONÇALVES, G.S.; PEZZATO, L.E.; BARROS, M.M. et al. Digestibilidade aparente e suplementação de fitase em alimentos vegetais para tilápia do Nilo. Acta Scientiarum, v.26, n.3, p.313-321, 2004.

GONÇALVES, G.S.; PEZZATO, L.E.; BARROS, M.M. et al. Efeitos de suplementação de fitase sobre a disponibilidade aparente de MG, $\mathrm{Ca}, \mathrm{Zn}, \mathrm{Cu}, \mathrm{Mn}$ e Fe em alimentos vegetais para tilápia do Nilo. Revista Brasileira de Zootecnia, v.34, n.6, p.2155-2163, 2005.

GUIMARÃES, I.G.; PEZZATO, L.E.; BARROS, M.M. et al. Nutrient digestibility of several grain products and by-products in extruded diets for Nile tilapia, Oreochromis niloticus. Journal of the Aquaculture Society, v.39, p.781-789, 2008.

HISANO, H.; PEZZATO, L.E.; BARROS, M.M. et al. Zinco e levedura desidratada de álcool como pró-nutrientes para alevinos de tilápia do Nilo (Oreochromis niloticus). Acta Scientiarum, v.26, n.2, p.171-179, 2004.

HISANO, H.; NARVÁEZ-SOLARTE, W.V.; BARROS, M.M. et al. Desempenho produtivo de alevinos de tilápia-do-Nilo alimentadas com levedura e derivados. Pesquisa Agropecuária Brasileira, v.42, n.7, p.1035-1042, 2007.

KHAW, H.L.; PONZONI, R.W.; DNTING, M.J.C. Estimation of genetic change in the GIFT strain of Nile tilapia (Oreochromis niloticus) by comparing contemporary progeny produced by males born in 1991 or in 2003. Aquaculture, v.275, p.64-69, 2008.

LI, P.; GATLIN, D.M. Evauation of brewers yeast (Saccharomyces cerevisiae) as a feed supplement for hybrid striped bass (Morone chrysops x M. saxatilis). Aquaculture, v.219, p.681-692, 2003.

MACHADO, P.F. Uso da levedura desidratada na alimentação de ruminantes. In: SIMPÓSIO SOBRE TECNOLOGIA DA PRODUÇÃO E UTILIZAÇÃO DA LEVEDURA DESIDRATADA NA ALIMENTAÇÃO ANIMAL, 1997, Campinas. Anais.. Campinas: CBNA, 1997. p.111-128.

MENTEN, J.F.M. Aditivos alternativos na nutrição de aves: probióticos e prebióticos. In: REUNIÃO ANUAL DA SOCIEDADE BRASILEIRA DE ZOOTECNIA, 30., 2001, Piracicaba. Anais... Piracicaba: SBZ, 2001. p.151-157.

NATIONAL RESEARCH COUNCIL - NRC. Nutrient requeriments of fish. Washington, D.C.: National Academy of Sience, 1993 $114 p$. 
PEZZATO, L.E.; MIRANDA, E.C.; BARROS, M.M. et al. Digestibilidade aparente de ingredientes pela tilápia do Nilo (Oreochromis niloticus). Revista Brasileira de Zootecnia, v.31, n.4, p.1595-1604, 2002.

PEZZATO, L.E.; MENEZES, A.; MARROS, M.M. et al. Levedura em dietas para alevinos de tilápia do Nilo. Veterinária e Zootecnia, v.13, n.1, p.84-94, 2006.

PONZONI, R.W.; HAMZAH, A.; TAN, S. et al. Genetic parameters and response to selection for live weight in the GIFT strain of Nile tilapia (Oreochromis niloticus). Aquaculture, v.247, p.203-210, 2005.
SIPAÚBA-TAVARES, L.H.S. Limnologia aplicada à aquicultura Jaboticabal: Funep, 1995. 72p.

SIGNOR, A. Levedura íntegra e levedura autolisada como pronutriente em dieta para reprodutores de tilápia do Nilo (Oreochromis niloticus). 2009. 70f. Tese (Doutorado em Zootecnia) - Universidade Estadual Paulista, Botucatu.

UNIVERSIDADE FEDERAL DE VIÇOSA - UFV. SAEG - Sistema para análises estatísticas e genéticas. Versão 7.1. Viçosa, MG, 1997. 150p.

ZAR, J.H. Biostatistical analysis. Englewood Cliff: PrenticeHall, 1999. 663f. 